\title{
Issue Highlights - September 2016
}

\author{
J. Philip McCoy Jr., PhD \\ NHLBI, NIH, Bethesda, MD
}

This issue of Cytometry Part B: Clinical Cytometry contains nine articles, eight of which examine topics related to hematopoietic neoplasms.

\section{NON-NEOPLASTIC T CELLS IN LYMPHOMAS AND LEUKEMIAS}

Three of these manuscripts do not directly study neoplastic cells in patient cohorts but rather present studies of non-neoplastic $\mathrm{T}$ cell populations found in patients with lymphoma or leukemia. In one study, Hunt and colleagues (1) describe the use of internal non-neoplastic T cells as controls in the evaluation of $\mathrm{T}$ cell neoplasms. The staining patterns of the normal $\mathrm{T}$ cells can function as a process control, assuring that all steps of sample preparation, staining, and analysis were performed correctly. Furthermore, with standardization of staining and analysis, these internal $\mathrm{T}$ cell can also be used as controls for the assessment of staining intensities in presumptively abnormal $\mathrm{T}$ cells. Caveats to this approach included the paucity of some T cell subpopulations in all patients and instrument to instrument variability in measuring staining intensities, highlighting the need for standardization in both staining and instrument set up.

In a second study Gunduz et al (2) examined peripheral blood T regulatory (Treg) cells in newly diagnosed lymphoma patients (both Hodgkin and non-Hodgkin). Increasingly, immune regulators and responses in patients with neoplasms are of interest, as these may tell if and how the abnormal cells are escaping immune surveillance. Recent examples include a study of natural killer (NK) cells and NK-like T cell populations in acute myeloid leukemia (3) and a study of memory and naïve T cells in chronic lymphocytic leukemia (4). Several additional studies have examined Treg cells in hematologic neoplasms $(5,6)$. In the current study Gunduz and coworkers look at Tregs (CD4+CD25highFoxP3+) in the peripheral blood of cohorts of Hodgkin lymphoma (HL) patients, non-Hodgkin lymphoma (NHL) patients, and healthy subjects and attempt to correlate the number of Tregs with a variety of patient characteristics. While a number of correlations were observed with prognostic factors in both HL and NHL patients, the only correlation observed with survival was in NHL patients where the number of Tregs inversely correlated with overall survival. These results, while preliminary, suggest that immune parameters might be feasible for use as prognostic markers, although much work remains to be done to precise how and why this can be done.

In related work, $\mathrm{Wu}$ and associates (7) queried whether reactive $\mathrm{T}$ cells in lymphocyte rich classical HL, nodular HL and T cell/histiocyte rich large B cell lymphoma could provide

*Correspondence to: J. Philip McCoy, Jr., PhD, NHLBI/NIH, 10 Center Dr, MSC 1357, Bldg 10, Rm 8C103D, Bethesda, MD. mccoyjp@mail.nih.gov. 
information of diagnostic utility. This study builds upon and extends the work of Seegmiller et al in which CD7 overexpressing T cells were identified in infiltrates of classical HL (8). In the current study a variety of phenotypes (T cells, CD4, CD8, B cell, NK cells dual positive $\mathrm{CD} 4+\mathrm{CD} 8+, \mathrm{CD} 7^{\text {bright }} \mathrm{T}$ cells) were examined in the infiltrates of these lymphomas and attempts were made to correlate these with the diagnoses. This study used cohorts to identify putative immune subsets linked to diagnoses and then a separate 387 specimen cohort, blindly evaluated, to confirm the utility of these subsets in diagnosis. This is an excellent example of how putative diagnostic markers should be tested. Based on their findings, the authors propose an algorithm that that might prove a useful adjunct in the diagnosis of these diseases. Naturally, this algorithm needs to be validated by other centers, but these findings also should drive future investigations into the biological function of these subsets in lymphomas.

\section{CD180 IN B CELL LYMPHOMAS}

This issue contains two manuscripts examining CD180 in B cell lymphomas $(9,10)$. The utility of CD180 is based just not on the presence or absence of this antigen, but also on the intensity of staining, similar to how CD200 is evaluated in B cell neoplasms (11). In a multicenter study, Mayeur-Rousse et al (9) demonstrate in blood and bone marrow samples that CD180 expression is strongly associated with marginal zone lymphoma (MZL), consistent with a previous report (12). They also show that CD180 is highly expressed on hairy cell leukemias (HCL). Also in this issue, Mestrallet and coworkers (10) examine CD180 expression in both the peripheral blood and lymph nodes from patients with follicular lymphoma (FL), chronic lymphocytic leukemia (CLL), mantel cell lymphoma (MCL), and marginal zone lymphoma (MZL), and well as from non-tumor-bearing controls. These authors again confirm the association of high levels of CD180 expression in the peripheral blood with MZL; however they extend these findings with the observation that CD180 expression is also high in the lymph nodes, but not peripheral blood, in cases of follicular lymphoma. These data suggest that the immediate environment could affect antigen expression, and that the sample source should be carefully considered when attempting to use CD180 to aid in diagnosis.

\section{CASE AND SERIES REPORTS: CD5+ HAIRY CELL LEUKEMIA AND SMALL ABNORMAL B LYMPHOBLASTS IN CHRONIC MYELOGENOUS LEUKEMIA $(\mathrm{CML})$}

Jain and associates (13) describe a case of CD5+ HCL and present a brief, but insightful review of CD5 expression in HCL and HCL variants. Their review indicates only slightly more than 2 dozen cases of HCL and HCL-v have been reported in the literature, with CD5 expression being more frequent if HCL-v rather than HCL. Case reports such as this and the Case Study Interpretation series (14-17) presented at the annual meeting of the International Clinical Cytometry Society are interesting training tools, and constant reminders that sometime 'rules' will be broken. 
In a report of a series of chronic myelogenous leukemia cases over a period of more than 7 years, Soma and colleagues (18) examine cases in which low percentages of abnormal B lymphoblast (ABLB) populations were present at diagnosis. A total of seven cases were identified, and interestingly the mean age of these patients was only 37 years old substantially less than most cases of CML at diagnosis. None of the patients with ABLB at diagnosis developed a lymphoid blast phase during follow-up, in contrast to a study by El Rassi et al (19), but consistent with a recent report in this journal by Vrotsos and colleagues (20). All three of these studies had limited numbers of patients, and since data appear to be controversial, clearly future large multi-institutional studies are warranted.

\section{TECHNICAL INNOVATIONS FOR THE CLINICAL LAB}

Finally, in this issue, there are two articles reporting technical innovations for the clinical laboratory. This journal is an excellent forum to share experiences with various techniques associated with clinical flow cytometry, and it is hoped that the readership will benefit from the current submissions $(21,22)$ as well as recently published technical reports $(23,24)$. Vallangeon and coworkers (21) studied the effects of tissue disaggregation methods on the immunophenotypic detection of diffuse large B cell lymphomas. These authors found that a manual disaggregation method resulted in detection of clonal B cell populations in more cases than did either mechanical processing or a combination of manual and mechanical dissociation. These finds held true for both nodal and extra-nodal tissue samples.

Cimato and colleagues (22) demonstrate the utility of seven color immunophenotyping to simultaneously distinguish populations of hematopoietic stem cells, multi-potent progenitor cells, common lymphoid progenitors, common myeloid progenitor cells, megakaryocyteerythrocyte progenitors, and granulocyte-macrophage progenitor cells in peripheral blood specimens. This panel should prove useful in providing a snapshot of stem and progenitor populations for longitudinal studies in individuals or in response to biological modifiers or therapy.

\section{Biography}

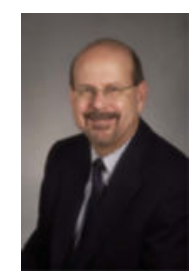

\section{J. Philip McCoy}

\section{REFERENCES}

1. Hunt AM, Shallenberger W, Ten Eyck SP, Craig FE. Use of internal control T-cell populations in the flow cytometric evaluation for T-cell neoplasms. Cytometry B Clin Cytom 2016.

2. Gunduz E, Sermet S, Musmul A. Peripheral blood regulatory T cell levels are correlated with some poor prognostic markers in newly diagnosed lymphoma patients. Cytometry B Clin Cytom 2016. 
3. Aggarwal N, Swerdlow SH, TenEyck SP, Boyiadzis M, Felgar RE. Natural killer cell (NK) subsets and NK-like T-cell populations in acute myeloid leukemias and myelodysplastic syndromes. Cytometry B Clin Cytom 2015129 10.1002/cyto.b.21349. [Epub ahead of print]

4. Monserrat J, Sanchez MÃ, de Paz R, Diaz D, Mur S, Reyes E, Prieto A, de la Hera A, Martinez-A C, Alvarez-Mon M. Distinctive patterns of naive/memory subset distribution and cytokine expression in CD4 T lymphocytes in ZAP-70 B-chronic lymphocytic patients. Cytometry B Clin Cytom 2014 1;86(1):32-43 [PubMed: 24166938]

5. Biancotto A, Dagur PK, Fuchs JC, Wiestner A, Bagwell CB, and McCoy JP: Phenotypic complexity of T Regulatory Cell Subsets in Patients with B-chronic Lymphocytic Leukemia. Mod Pathol 25: 246-259, 2012. [PubMed: 22101351]

6. Raja KR, Plasil M, Rihova L, Pelcova J, Adam Z, Hajek R. Flow cytometry-based enumeration and functional characterization of CD8 T regulatory cells in patients with multiple myeloma before and after lenalidomide plus dexamethasone treatment. Cytometry B Clin Cytom 2014 7;86(4):220-8. [PubMed: 23922218]

7. Wu D, Thomas A, Fromm JR. Reactive T cells by flow cytometry distinguish Hodgkin lymphomas from T cell/histiocyte-rich large B cell lymphoma. Cytometry B Clin Cytom 2016.

8. Seegmiller AC, Karandikar NJ, Kroft SH, McKenna RW, Xu Y. Over-expression of CD7 in classical Hodgkin lymphoma-infiltrating T lymphocytes. Cytometry Part B: Clin Cytom 2009 5; 76B(3) 169174 ,

9. Mayeur-Rousse C, Guy J, Miguet L, Bouyer S, Geneviève F, Robillard N, Solly F, Maar A, Bené MC, Mauvieux L; GEIL (Groupe d'Etude Immunologique des Leucémies). CD180 expression in Bcell lymphomas: A multicenter GEIL study. Cytometry B Clin Cytom 2016.

10. Mestrallet F, Sujobert P, Sarkozy C, Traverse-Glehen A, Callet-Bauchu E, Magaud JP, Salles G, Baseggio L. CD180 overexpression in follicular lymphoma is restricted to the lymph node compartment. Cytometry B Clin Cytom 2016.

11. Sandes AF, de Lourdes Chauffaille M, Oliveira CR, Maekawa Y, Tamashiro N, Takao TT, Ritter EC, Rizzatti EG. CD200 has an important role in the differential diagnosis of mature B-cell neoplasms by multiparameter flow cytometry. Cytometry B Clin Cytom 2014 3; 86(2):98-105. [PubMed: 24243815]

12. Miguet L, Lennon S, Baseggio L, Traverse-Glehen A, Berger F, Perrusson N, Chenard MP, Galoisy AC, Eischen A, Mayeur-Rousse C, Maar A, Fornecker L, Herbrecht R, Felman P, Van Dorsselaer A, Carapito C, Cianferani S, Mauvieux L. Cell-surface expression of the TLR homolog CD180 in circulating cells from splenic and nodal marginal zone lymphomas. Leukemia 2013 8;27(8):174850. [PubMed: 23302770]

13. Jain D, Dorwal P, Gajendra S, Pande A, Mehra S, Sachdev R. CD5 positive hairy cell leukemia: A rare case report with brief review of literature. Cytometry B Clin Cytom 2016.

14. Balog A, Meyerson H. Case study interpretation-Fort Lauderdale: Case 1. Cytometry B Clin Cytom 2015 Nov-Dec;88(6):396-9. [PubMed: 24488704]

15. Paessler M Case study interpretation-Fort Lauderdale: Case 2. Cytometry B Clin Cytom 2015 Nov-Dec;88(6):400-3. [PubMed: 24488725]

16. Deeb G, Wang E, Wallace P. Case study interpretation-Fort Lauderdale: Case 3. Cytometry B Clin Cytom 2015 Nov-Dec;88(6):404-7. [PubMed: 24677776]

17. Fuda FS. Case study interpretation-Fort Lauderdale: Case 4. Cytometry B Clin Cytom 2015 NovDec;88(6):408-12. [PubMed: 24488761]

18. Soma L, Oehler VG, Ding C, Cherian S. Small, abnormal B lymphoid blast populations in Chronic Myelogenous Leukemia at diagnosis: Does this finding indicate an accelerated course? Cytometry B Clin Cytom 2016.

19. El Rassi F, Bergsagel JD, Arellano M, Gaddh M, Jillella A, Kota V, Heffner LT, Winton EF, Khoury HJ. Predicting early blast transformation in chronic-phase chronic myeloid leukemia: is immunophenotyping the missing link? Cancer 20153 15;121(6):872-5. [PubMed: 25387987]

20. Vrotsos E, Gorgan M, DiGiuseppe JA. Detection of small abnormal B-Lymphoblast populations at diagnosis of chronic myelogenous leukemia, BCR-ABL11: Incidence, phenotypic features, and clinical implications. Cytometry B Clin Cytom 2016. 
21. Vallangeon BD, Tyer C, Williams B, Lagoo AS. Improved detection of diffuse large B-cell lymphoma by flow cytometric immunophenotyping-Effect of tissue disaggregation method. Cytometry B Clin Cytom 2016.

22. Cimato TR, Furlage RL, Conway A, Wallace PK. Simultaneous measurement of human hematopoietic stem and progenitor cells in blood using multi-color flow cytometry. Cytometry B Clin Cytom 2016.

23. Boyd JD, Smith GD, Hong H, Mageau R, Juskevicius R. Fine-needle aspiration is superior to needle core biopsy as a sample acquisition method for flow cytometric analysis in suspected hematologic neoplasms. Cytometry B Clin Cytom 2015 1;88(1):64-8. [PubMed: 25196066]

24. de Jongste AH, Kraan J, van den Broek PD, Brooimans RA, Bromberg JE, van Montfort KA, Smitt PA, Gratama JW. Use of TransFix; cerebrospinal fluid storage tubes prevents cellular loss and enhances flow cytometric detection of malignant hematological cells after 18 hours of storage. Cytometry B Clin Cytom 2014 7;86(4):272-9. [PubMed: 23674509] 